\title{
LA CUESTIÓN DEL NIHILISMO EN J. G. HAMANN
}

CINTA CANTERLA

Universidad Pablo de Olavide de Sevilla

\begin{abstract}
RESUMEN: Este artículo analiza los elementos de la metacrítica de la llustración de Hamann que permiten remontar a su filosofía el nacimiento de la forma contemporánea que presenta la cuestión del nihilismo, patentes esencialmente en el tratamiento que realiza de la imagen de los falsos silenos o silenos invertidos (máscaras de falsa apariencia brillante) para denunciar como irracionalidad el dogmatismo de cierta concepción absoluta de la razón conducente a una falsa filosofía.
\end{abstract}

PALABRAS CLAVE: Hamann, metacrítica, nihilismo, Ilustración, Kant.

\section{J.G. Hamann and the question of nihilism}

ABSTRACT: This paper analyzes the elements of the Hamann's metacritic of the Enlightenment that allow to locate in his philosophy the birth of the contemporary form that present the question of nihilism. Manifest essentially in the treatment that he implements to the image of false or inverted silenus, with the purpouse of denouncing the irrationality of the dogmatism in certain absolute conception of reason, that leads to a false philosophy.

KEY WORDS: Hamann, metacritic, nihilism, Enlightenment, Kant.

«Cada vez que ha habido que erradicar la enfermedad de una nueva idolatría, el Sacerdote encargado de la higiene pública ha visto en ello una oportunidad de acrecentar sus finanzas» 1 .

En su obra Evocación de Sócrates ${ }^{2}$ (1759) Hamann lleva ya a cabo una crítica de la intelectualidad ilustrada utilizando como imagen clave la figura de Sócrates y manifestando su compromiso con la labor de desenmascarar a los nuevos sofistas. El núcleo de la misma gira en torno a la falacia que él observa en la demarcación racionalidad/ irracionalidad, salud e insanía, que estos establecen, que les lleva finalmente a negar y disolver en la nada la realidad en la que el hombre vive cotidianamente, invirtiendo los valores y suplantando la vida por la palabrería y los sistemas.

Pero su crítica tiene también como eje central un análisis de la cuestión de la autoría y del modo en que el poder de las redes intelectuales, derivado muchas veces del mecenazgo de los política y socialmente poderosos, forma parte del proceso por el que se acaban convirtiendo en gran filosofía teorías y sistemas que no son más que mera vaciedad pedante. Y puesto que él se propone como meta realizar la crítica del enciclopedismo

\footnotetext{
1 Hamann, J. G., Sokratische Denkwürdigkeiten für die lange Weile des Publicums zusammengetragen von einem Liebhaber der langen Weile. Mit einer doppelten Zuschrift an Niemand und Zween, en HamanN, J. G., Sämtliche Werke. Edición crítica de NAdler, J. Vol. II. Wien, Verlag Herder, 1950, p. 80, líneas 17-18. A partir de aquí, las referencias a esta edición se harán siguiendo la convención: N, seguido del número del volumen, número de la página y número de las líneas (N II 80 17-18). El texto es una alusión velada a Federico II de Prusia y su despotismo ilustrado, extrapolando al mismo la crítica de Erasmo al Papa.

2 Una obra que los intérpretes han comparado a Los orígenes de la tragedia de Nietzsche en cuanto escrito fundacional de la crítica hamaniana. Cf. O`FlaHerTy, J. C., «Sócrates in Hamann’s Socratic Memorabilia and Nietzsche Birth of Tragedy: A Comparyson", en Ph. Merlan y Palmer, R.B., Philomates. Studies and Essays in the Humanities in Memory Ph. Merlan. La Haya, Brills Academia Publishers, 1071, pp. 307329. La Evocación de Sócrates, dedicada a sus amigos Kant y Berens, era la primera obra de Hamann en sentido estricto.
} 
francés y la filosofía académica alemana en un momento en el gozan de un prestigio casi incuestionable, se refugiará detrás de la máscara de Sócrates ${ }^{3}$ para denunciarlos como silenos contrarios o falsa filosofía.

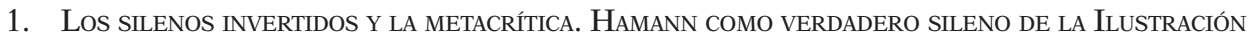

El recurso al filósofo griego no era una novedad en el s. XviII. Sí lo era, en cambio, la utilización de esa figura, que representaba para los ilustrados la esencia del racionalismo griego y que había sido uno de los grandes iconos de los enciclopedistas, para realizar precisamente la crítica profunda de la Ilustración. Y ello, echando mano de un elemento ya empleado por Erasmo y bajo su influencia: la imagen de la máscara, del sileno (y especialmente la del sileno contrario, invertido o al revés), como clave de la crítica a la perversión, a su vez invertida, de los valores.

Hamann va a utilizar la figura de Sócrates con la fuerza de una reivindicación pasional. Atrás quedaba la honda crisis personal que había llevado a su autor, primero, a un escepticismo radical en relación a los modelos religiosos y filosóficos de pensamiento y de lenguaje de su tiempo, y después, tras la experiencia límite de un doloroso autoconocimiento ${ }^{4}$, a una piedad por el hombre y su existencia que se le evidenciaba el mejor asiento para una filosofía verdadera, el antídoto contra la arrogancia, la pedantería y la vacuidad de una razón abstracta. Si había estado a punto de sucumbir al nihilismo de ésta, ahora veía en cambio nítida la superstición de las modas intelectuales, la disolución de la realidad en el vacío por parte de construcciones abstractas que se acababan superponiendo a la vida invirtiendo todos sus valores. Y en la experiencia de esa clarividencia y esa nueva sabiduría se identificaba con Sócrates: el Sócrates para el que el no saber era una forma de experiencia, de vivencia, de sabiduría existencial. Por ello, Sokratische Denwürdigkeiten no es sólo un homenaje intelectual al filósofo griego, sino una declaración de principios de lo que va a ser la filosofía hamaniana.

Hamann ve en Sócrates - y también en Hume, como abordaremos más adelanteel gran sileno del escepticismo: por fuera, su sólo sé que no sé nada; por dentro, su sensualidad, su humanidad, su sociabilidad, su creencia (que es sobre todo sentimiento y esperanza). Pero también se ve a sí mismo como el gran sileno de su tiempo: en su exterior, disolvente con las certezas de la época, negador de los sistemas especulativos, y crítico con la teología y las escolásticas de cualquier naturaleza; en su interior, portador de una nueva época de la filosofía. Y así, lacra a veces sus cartas con un sello con la efigie de Sócrates ${ }^{5}$ y hasta su amigo Herder se refiere a él literariamente como «querido

\footnotetext{
3 «Sea como sea, esta situación original (el recurso a Sócrates en Platón) ha dejado una profunda huella en la conciencia occidental, y cuando algunos pensadores tomaron conciencia - y se asustaronde la renovación radical que estaban aportando, utilizaron una vez más una máscara, y de preferencia la máscara irónica de Sócrates, para enfrentarse a sus contemporáneos». НAdot, P., Elogio de Sócrates. Buenos Aires, Paidós, 2008, pp. 19 y 20.

4 «También Hamann, quizá más radicalmente aún que Lessing, ha vivido el abandono de las comprensibilidades automáticas de los modelos tradicionales, religiosos y también racionalistas, de pensamiento y de lenguaje y el giro hacia la experiencia de la autorreflexión, ante todo como una honda crisis personal». RüHLE, V., En los laberintos del autoconocimiento. Madrid, Akal, 1997, p. 30.

5 Carta de Herder a Hamann de entre el 10 y el 13 de agosto de 1764. En Herders Briefe an Johann Georg Hamann. Ed. de Hoffmann, O. Hildesheim, Olms, 1975. Reproducción de la edición de Berlín, R. Gaertners Verlagsbuchhandlung, 1889. «Kanter presume a costa de usted a propósito del sello con la cabeza de Sócrates, tanto delante de mi como de su padre. ¿Se lo ha enviado ya?». P. 5, líneas 19-20. El
} 
Sócrates», "viejo Padre Sileno», o «Demon» en su correspondencia, desde la primera carta de1764 y al menos hasta las de $1775^{6}$.

La recuperación para la modernidad de la imagen del sileno y su utilización para criticar el recubrimiento - y encubrimiento - de la realidad con una falsa apariencia que la niega, avalada por la erudición y un lenguaje engañoso, la hizo por primera vez Erasmo de Rotterdam, que la utilizó en su crítica religiosa, política y social en dos direcciones: el sileno y el sileno invertido. La fuente originaria a la que se remitía, como veremos enseguida, era el recurso a esa imagen en El Banquete de Platón, en el discurso de Alcibíades, para representar la contraposición entre apariencia y realidad:

«A Sócrates, señores, yo intentaré alabarlo de la siguiente manera: mediante imágenes. El quizá creerá que lo hago para ridiculizarlo, pero la imagen tendrá como finalidad la verdad, no la burla. Afirmo, en efecto, que él se asemeja mucho a los silenos esos que se encuentran en los talleres de los escultores, que elaboran los artesanos llevando siringas o flautas y que, abiertos en dos, se ve que tienen en su interior estatuas de dioses. Y afirmo además que se parece al sátiro Marsias...» $\gg^{7}$

«Pero escuchadme cuán semejante es en otros aspectos a aquellos con quienes lo he comparado y cuán asombroso poder tiene. Pues sabed bien que ninguno de vosotros lo conoce, pero yo os lo mostraré, ya que he empezado. Veis, en efecto, que Sócrates siente una amorosa predisposición por los bellos muchachos y siempre está entorno a ellos y queda estupefacto, y, por otra parte, que lo ignora todo y nada sabe. Su aspecto externo, al menos, ¿no es propio de un sileno? Sin duda alguna. Con eso, en efecto, él está recubierto por fuera, como un sileno esculpido; pero por dentro, una vez abierto, ¿de cuánta templanza creéis que está lleno, compañeros de bebida? Sabed que no le importa nada si alguien es bello, sino que lo desprecia hasta un extremo que nadie podría creer, ni tampoco si alguien es rico ni si posee alguna otra distinción de las que la multitud estima venturosas. Al contrario, considera que todas esas posesiones no valen nada y que nosotros no somos nada (os lo digo yo), y se pasa la vida entera ironizando y bromeando con los hombres. Pero cuando habla en serio y se abre, no sé si alguien ha visto esas estatuas en su interior. Yo las he visto una vez, y me pareció que eran tan divinas y áureas, tan extraordinariamente bellas y maravillosas, que había que hacer al instante lo que ordenase Sócrates» ${ }^{8}$.

Esa imagen del sileno - referida, pues, no a un sátiro, sino a ese cofre de forma de sátiro- había reaparecido en el Renacimiento, antes de que la usase Erasmo, en Pico de

Editor añade en nota a pie de página este comentario a la línea 19: «Las cartas de Hamann a veces iban selladas con una cabeza de Sócrates». También llevaba este sello al pie el fragmento de Hamann Ausblick, de 1774, reproducido en N III 9, bajo el cual aparece indicado en la edición: rotes Lacksiegel, Kopf des Sokrates nach links.

6 Cartas de Herder a Hamann: Hamman como nuevo Sócrates, en carta de 21 de mayo de 1761, p. 166 («Yo lo veo a usted a menudo como un Sócrates...») y de finales de abril de 1768, p. 41; Hamann como Sócrates y Herder como Alcibíades fallido, en carta de 1 de agosto de 1772, p. 67 11-12 («Déjeme que le recomiende, viejo amado Sócrates, un Alcibíades que desgraciadamente no soy yo.»); el Daemon socrático de Hamann, en carta de 2 de enero de 1773, p. 71 33; Hamann como Sileno, carta de comienzos de mayo de 1774, p. 80 21-22 ( CCréame, querido y ancestral Padre Sileno,...»). Hamann había ya usado antes en una carta a Kant de 27 de julio de 1759 la imagen literaria de la dualidad Sócrates-Alcibíades, refiriéndose con cortesía a Kant como Sócrates y otorgándose él mismo el papel de Alcibíades: «Sea usted Sócrates, que yo seré Alcibíades». En Johann Georg Hamann Briefwechsel. Vols. 1-3, ed. de Walter Ziesemer y Arthur Henkel; vols. 4-7, ed. de Arthur Henkel. Frankfurt/Main, Insel Verlag, 1955-1979. Vol. I, nº 153, p. 373, línea 28. A partir de aquí, esta edición de la correspondencia de Hamann se citará siguiendo la convención: $\mathrm{ZH}$, seguido del número del volumen, $\mathrm{n}^{\circ}$, seguido del número de la carta, y finalmente número de línea (ZH I n 153373 28).

7 Platón, El Banquete. Introducción de García Gual C., traducción y notas de García Romero, F. Madrid, Alianza Editorial, 2008 ( $9^{\mathrm{a}}$ reimp.). 215a-b.

8 Platón, El Banquete, 216c-e 
la Mirándola, en la argumentación de una carta de 1485 dirigida al humanista Hermolao Bárbaro en la que defendía a la filosofía escolástica comparándola con «los silenos de Alcibíades». Según Pico, bajo su apariencia tosca y su latín degenerado se escondía un tesoro, un significado elevado y verdadero accesible sólo a unos pocos.

«Si dices que para el vulgo pasamos por sórdidos, rudos incultos, esto cede más en nuestra gloria que en nuestro deshonor; no escribimos para el vulgo (...). También los que quieren ocultar sus tesoros, si no los pueden apartar lejos, suelen taparlos con barreduras y cascotes, para que los que pasan al lado no los descubran, si no son aquellos solos que se hubieren hecho dignos de tal favor. Similar es el empeño de los filósofos en celar sus cosas al pueblo, del cual no sólo no pueden esperar que los apruebe, pero ni que los entienda (...). Pero quieres que te aclare la idea de nuestro alegato. Es la mismísima que la de los silenos de Alcibíades; sus estatuas presentaban un rostro horripilante, triste y vil, pero dentro estaban llenos de joyas, de recamados y raros vestidos. Por eso si de fuera lo miras, verás una fiera, si por dentro un numen»?

Erasmo de Rotterdam recogerá este recurso a los silenos de Alcibíades de Pico, pero dándole una nueva dimensión que la hará verdaderamente potente para sus intereses críticos. Así, por un lado la utilizará para resaltar el contraste entre una apariencia modesta, poco importante o incluso vil y un interior espiritualmente elevado, y se referirá con ella a Sócrates, Antístenes, Diógenes, Epicteto o incluso al mismo Cristo ${ }^{10}$, viendo en los mismos Silenos positivos; pero igualmente la utilizará para identificar fraudes de contrario: los que cometen aquellos que engañan con una apariencia brillante supuestamente valiosa pero que no tienen en su interior más que vacío. Es esta última la imagen erasmiana de los silenos invertidos o al revés, entre los que se encontrarán la falsa filosofía y la teología escolástica pero también personas, valores o imágenes de un mundo social y cultural que se superpone al natural, muchas veces negándolo. De este modo, falsos silenos que engañan al pueblo con su apariencia y su prestigio lo son, entre otros, el Papa Julio II, la Guerra Santa, el monarca absoluto o la teología escolástica aristotélica.

Pero Erasmo tomará además directamente de El Banquete otro elemento esencial en su elaboración de la imagen de las máscaras silénicas: la cuestión del lenguaje. La crítica al vacío existente tras la apariencia de saber de ciertos discursos está presente igualmente en el texto de Platón y referida a los sofistas, en especial en la contraposición que establece Sócrates entre un discurso formalmente culto, abstracto, que sigue los cánones retóricos establecidos para ello por las élites intelectuales, y aquel otro espontáneo que surge de la expresión natural del deseo de hablar con verdad y que se basa en las propias vivencias. El contraste se reitera también en la intervención de Alcibíades, al oponer el joven el discurso del orador Pericles al de Sócrates, este último el que de verdad convence los corazones, a pesar de la brillantez del primero y de las apariencias.

Con estos elementos, Erasmo sostendrá en su crítica que una parte muy importante del prestigio de los falsos silenos se construye, de un lado, administrando un lenguaje experto al que no tiene acceso el hombre de a pie, y, de otro, imponiendo al pueblo un lenguaje ideológico generador de falsa conciencia, enmascarador, que hace vivir al

9 Carta de Juan Pico de la Mirandola a Hermolao Bárbaro, en Pico de la Mirandola: De la dignidad del hombre. Con dos apéndices: Carta a Hermolao Barbaro y Del ente y el uno. Trad. De Luis Martínez Gómez. Madrid, 1984, pp. 148 y ss. La referencia la conocí por M. A. Granada, en Erasmo de Rotterdam: Escritos de crítica religiosa y política. Estudio preliminar, traducción y notas de M. A. Granada. Madrid, Tecnos, 2008. Entre las páginas XXXV y XVI se refiere a la cuestión de los silenos en Erasmo.

10 ERASmo de RotTerdam, «Silenos de Alcibíades» en Erasmo de Rotterdam: Escritos de crítica religiosa y política, pp. 75-82. 
hombre en un mundo virtual de apariencias donde los valores se invierten según los intereses de los que detentan el poder religioso, social, político e intelectual. Este es el caso, por ejemplo, de la Escolástica y del Papado ${ }^{11}$, que han utilizado este recurso para falsear el cristianismo y enriquecerse.

Hamann va a utilizar esta teoría erasmiana de las máscaras y su concepción de la alerta crítica permanente para elaborar su propia crítica de la Ilustración. Siguiendo a Hume, concebirá inicialmente la verdadera filosofía como crítica escéptica, pero irá reelaborando poco a poco el escepticismo humeano ${ }^{12}$ para dar origen a un paradigma filosófico nuevo que, recogiendo la funcionalidad que el escepticismo había desempeñado en la filosofía clásica (entendiendo por clasicismo la filosofía comprendida entre la socrática y la ilustrada) hacía de la deconstrucción, la inversión y el desenmascaramiento el método por excelencia de un existencialismo radicalmente contracultural. De ahí que concibiese la filosofía como metacrítica: crítica de una crítica, que a su vez es sobrepasada por una nueva, en una tarea sin descanso.

Y así, su crítica de la Ilustración no sólo irá destinada a los autores de su vertiente más dogmática, sino también a sus críticos más heterodoxos. Buscaba una nueva filosofía verdaderamente emancipadora que constituyese ella misma la verdadera Ilustración, salvando el verdadero espíritu de esta última frente a los que la habían traicionado. No era, pues, un contrailustrado, de la misma forma que tampoco Erasmo era un anticristiano: no buscaba una involución reaccionaria, sino sobrepasar el proyecto emancipador de la modernidad para llevarlo más lejos. Así, Herder diría después que la metacrítica era el protestantismo de la Ilustración ${ }^{13}$ :

Erasmo había expuesto directamente la cuestión de las máscaras silénicas en Silenos de Alcibíades, uno de los proverbios recogidos en su obra Adagia, que debido a su extensión y a su interés fue editado también de modo independiente separado del conjunto, traduciéndose al alemán en 1520, al español en 1529 y al inglés en 1543. La edición que Hamann tenía en su biblioteca, entre otras obras de Erasmo, era la completa de los Adagia que se hizo en Colonia en $1612^{14}$. El proverbio Silenos de Alcibíades vio la luz por primera vez en la edición aldina de Venecia en 1508, con el número 2201, limitado a un

11 Erasmo de Rotterdam, «Julio II excluido del Reino de los Cielos». En Erasmo de Rotterdam: Escritos de crítica religiosa y política, pp. 3-68.

12 «Un espíritu para demoler, no para construir. En eso consiste la gloria de Hume. Nosotros demolemos y construimos (todo tiene su tiempo), aunque resulte fatuo que yo lo diga». Carta a Lindner de 21 de marzo de 1759. ZH I n 139305 18-20.

13 «¿Acaso tenemos un deber y un don más grande que el uso libre e íntimo de nuestro pensamiento? La metacrítica es, pues, protestantismo; protesta frente a todo papismo dogmático, impuesto acrítica o afilosóficamente a la razón y al lenguaje». Herder, J. G., Verstand und Erfahrung. Eine Metakritik zur Kritik der reinen Vernunft. Erster Teil. En Sämmtliche Werke, ed. de SupHan, B. (Repro. de Berlin, Weidmann, 1877-1913, 33 vols). Hildesheim, Olms, 1967-68. Vol. XXI, p. 12. Vers. cast., Herder, J. G., Una metacrítica de la Crítica de la razón pura, en Obra Selecta. Prólogo, traducción y notas de P. Ribas. Madrid, Alfaguara, 1982, p. 371.

14 Biga Bibliotecarum N V 45 59/21. Lindner tenía también los Adagia en su biblioteca, pero en la edición de 1643 (Biga N V 45 58/8). En 1500 Erasmo había publicado una obra embrionaria, Adagiorum collectanea, recopilación de 818 proverbios antiguos impresa con precipitación con la finalidad inmediata de conseguir algunos ingresos; en 1507-1508 salió en París la segunda edición, que sólo añadía veinte nuevos proverbios; pero tras un trabajo intensivo en Italia entre 1506 y 1509 la obra se transformó espectacularmente, de tal manera que la edición que hizo Aldo Manucio en Venecia en 1508 contenía ya tres mil doscientos sesenta adagios numerados, acompañados de comentario. Las ediciones posteriores que fueron apareciendo en vida de Erasmo (1515, 1517-1518, 1520, 1523,1526, 1528, 1533 y 1536) recogieron reflexiones cada vez más amplias e incluso verdaderos ensayos, convirtiéndose en una obra de crítica social, política y religiosa que acabaría conteniendo 4151 proverbios. 
breve comentario filológico que sigue al enunciado del mismo; es en la edición siguiente, la de Basilea de 1515, cuando adquiere las dimensiones de un largo ensayo de crítica política y religiosa.

El tema había aparecido embrionariamente en 1504 en el Enchiridion militis christiani, el Manual del soldado cristiano, una obra que formaba parte del volumen $\mathrm{Lu}$ cubrantiunculae; se publicó como proverbio, pero en la versión escueta, en 1508; se desarrolló en el Elogio de la locura de 1511; hasta ver la luz como un ensayo amplio en la citada edición de los Adagia de 1515. Un trabajo que, aunque recogía un motivo clásico aparecido en El Banquete, tenía gran originalidad. Así, a propósito de este proverbio, dice M. A. Granada:

«Aunque Erasmo se esfuerza desde las primeras líneas por presentar el motivo de los Silenos de Alcibíades como un proverbio griego recogido ya como tal en los paremiógrafos, lo cierto es que se trata de un proverbio acuñado por él a partir de unas pocas pero muy importantes fuentes literarias y de la gran utilidad que creyó percibir en la expresión para designar el carácter equívoco de la apariencia frente a una realidad conflictiva con ella. La fuente literaria última es el pasaje del Banquete platónico en el que Alcibíades caracteriza a Sócrates como sileno (...)»15

En el Elogio de la locura Erasmo había contrapuesto la locura negativa de las diferentes ocupaciones mundanas, que ponen su valor en la apariencia, y la locura positiva del cristianismo auténtico, que es estulticia a ojos del mundo, pero verdadera sabiduría a los de Dios. El motivo de los silenos y del enmascaramiento se convierte ya en ella en la clave de lectura de la realidad, escindida siempre entre una apariencia engañosa y la realidad íntima y verdadera, con el consiguiente engaño en el juicio y la valoración.

Y desde esta clave de lectura crítica el conocimiento aparente y la moral se muestran ya en el Elogio atravesados por conceptos y palabras engañosos, un velo que hay que apartar transformando cada elemento en su contrario (esto es, invirtiendo las oposiciones, subvirtiendo tanto el valor como la indignidad aparentes). Ahora bien, no será hasta Silenos de Alcibíades cuando la sospecha se muestre como elemento esencial de la crítica: Erasmo advertirá entonces de la superposición engañosa de las máscaras y de la necesidad de hacer de la hermenéutica de inversión de las oposiciones un elemento constante en las relaciones con el mundo social, pues este se encuentra atravesado por la voluntad de encubrimiento.

Así, no es sólo que lo aparentemente feo, insignificante o sencillo pueda estar, si se abre como el sileno, lleno de sabiduría, belleza, elevación y moralidad; sino además —y es aquí donde reside toda la carga de la crítica religiosa y social de Erasmo- que lo que aparenta sabiduría, lo que socialmente se acepta como bondad, religiosidad, belleza, dignidad, teología o filosofía, convenientemente mirado en su interior, quizá no sea más que puro vacío. Son estos últimos, los grandes y falsos ídolos sociales, los que Erasmo llamará silenos invertidos.

«Nadie ignora que todas las cosas humanas, como los silenos de Alcibíades, tienen dos caras, totalmente diferentes. Lo que a primera vista es, como si dijéramos muerte, visto desde dentro es vida y viceversa; la vida es muerte. La belleza, fealdad; la opulencia, pobreza; la infamia, gloria; la sabiduría, ignorancia; la fuerza, debilidad; la nobleza, plebeyez; la felicidad, tristeza; la buena fortuna, adversidad; la amistad, enemistad;

15 Granada, M. A., Estudio preliminar a Erasmo de Rotterdam: Escritos de crítica religiosa y política, pp. XXXV y XXXVI. 
la salud, enfermedad. En suma que si abres el sileno, de repente, te quedarán cambiadas las cosas ${ }^{16}$.

Ahora bien, como ya hemos indicado, para Erasmo la clave de esa cortina desvirtuadora que oculta el verdadero ser de las cosas es la forma lingüística que adopta, que tiene su asiento esencial en un ejercicio de manipulación y subversión lingüísticas. De este modo, un lenguaje desvirtuado y abstracto da lugar a un mundo intermedio ilusorio en el que las gentes se ven obligadas a vivir disociándose de su verdadera experiencia del mundo, que resulta negada. Sólo perversamente, una Guerra, una Liga o un Papa canalla pueden ser Santos, el cristianismo degenerado una religión, o un rey tiránico un benévolo padre. El lenguaje resulta ser, pues, el lugar privilegiado del enmascaramiento, allí donde los silenos se van superponiendo hasta la nada, impidiendo vivir con autenticidad. Aunque también el vulgo tiene los suyos y su responsabilidad en no pensar por sí mismos y desenmascararlos ${ }^{17}$.

La imagen del sileno sirve, pues, de modelo a Erasmo para esta teoría de la máscara que critica la disolución de la realidad en el vacío de una construcción cultural abstracta que se le acaba superponiendo pervirtiendo los valores naturales. El traductor de Erasmo al castellano, Bernardo Pérez, lo dice así en nuestra lengua en 1529:

«(...) por culpa de nosotros mesmos nos ponemos muchas máscaras y un mesmo hombre hay mucha diversidad de rostros dentro del ánimo; y ansí como en las farsas y comedias un mesmo personaje sale hecho un Hércules fuerte y luego torna a salir una delicada dama y luego una vieja que toda tiembla, así nosotros, que no fuésemos del mundo, aborreceríamos del mundo tantas máscaras, como si dijese: tantos silenos $(\ldots))^{18}$.

Ahora bien, la finalidad última de la crítica erasmiana era la salvación religiosa. Para Erasmo, un mundo verdaderamente cristiano sería un mundo sin silenos ni máscaras, en la que la pietas de la autenticidad estuviese centrada en la vida y la filantropía. Sólo así se alcanzaría la vida inmortal, aquella en la que «...ya no serán variables nuestros

16 Erasmo de Rotterdam, Elogio de la locura. Trad. de P. Rodríguez Santidrián. Madrid, Alianza,1984, p. 65 .

17 «Y destas falsas opiniones también tuercen los vocablos de las cosas. Llaman bajo a lo que de veras es alto, dulce a lo amargo, precioso a lo vil, vida a la muerte. Y por darte un gusto destas cosas en particular, mira qué de errores tiene el vulgo: llaman amor al regalo corrompedor de buenas costumbres; dicen que te aman aquellos que procuran corromper tu buena fe o castidad, como quiera que ninguna obra pueda ser de más enemigo. Llaman justicia dando mal por mal, injuria por injuria, venganza doblada por ofensa sencilla (...) Llaman traidor y enemigo del príncipe al que dice que no puede ni debe hacer contra las leyes ni contra igualdad, al que desea que sea verdadero príncipe, no tirano pestilencial y cruel (...) Llaman engrudo y soldadura de la paz cristiana los parentescos de los reyes, aquellas treguas, ligas y pactos que hacen y deshacen a cada paso, como quiera que destas fuentes veamos nacer todas las guerras y males del mundo (...) Llaman paz cuando para robar el mesmo pueblo se tornan a concertar (...) Llaman asimesmo Iglesia a los sacerdotes, obispos y sumos pontífices; y a la verdad estos no son otra cosa sino ministros de la iglesia. La Iglesia es todo el pueblo cristiano (...) Luego descomulgan y llaman enemigos de la Iglesia y herejes a los que engañan en algo la renta pontificial (...) Dicen está muy honrada y acrecentada la iglesia no cuando crece la religión y florece la doctrina, pero cuando los altares relucen con oro, con perlas (...)». Erasmo de Rotterdam: «Silenos de Alcibíades». Traducción castellana del siglo xvi de Bernardo Pérez de Chinchón, recogida en la antología ya citada, Erasmo de Rotterdam: Escritos de crítica religiosa y política. Estudio preliminar, traducción y notas de M. A. Granada, pp. 91-92, 94-96. Utilizo esta traducción porque evidencia ya el uso antiguo en castellano de la equivalencia entre sileno y máscara.

18 ERASmo de RotTerdam, «Silenos de Alcibíades». En Erasmo de Rotterdam: Escritos de crítica religiosa y política. Estudio preliminar, traducción y notas de M. A. Granada, pp. 119-120. 
deseos y el sileno será todo hermoso dentro y fuera» ${ }^{19}$. La labor de la crítica sería, pues, disolver las máscaras para poder dejar espacio a la verdadera religión. En Hamann, en cambio, esa crítica pretende abrir espacio, mediante el desenmascaramiento, a la verdadera filosofía, denunciando las consecuencias políticas e intelectuales alienantes de cierta ilustración dogmática utilizando contra ellas sus mismas armas.

Porque también él usará el encubrimiento. Para Hamann las máscaras forman parte activa de la propia crítica filosófica, elemento esencial, a su vez, para el desenmascaramiento de los falsos silenos, y las utilizará con frecuencia: enmascararse para desenmascarar, esta será su estrategia ${ }^{20}$. Su encanto seductor — como el de Sócrates- estará precisamente en su opción metodológica por la superposición de apariencias: en muchas de sus publicaciones jugará irónicamente a ocultarse bajo una, debajo de la cual hay otra y detrás de esta una tercera, y así sucesivamente. Y es que es muy consciente de que la batalla de la filosofía se libra ya no en el solipsismo del gabinete, sino en el espacio de la opinión pública, de forma que es en él en el que desarrolla sus estrategias críticas de educador. En su correspondencia privada, en cambio, abandona los juegos de encubrimiento y se muestra de forma directa, lo que nos permite valorar adecuadamente — por contraste_ la estrategia de sus escritos impresos como una elección consciente.

Hamann usará las imágenes de Alcibíades, de los silenos y de Sócrates en sus obras ${ }^{21}$ para llevar a cabo la crítica a la mala filosofía y a todas las falsas apariencias del mundo intelectual de su tiempo ${ }^{22}$, y ello antes de que comenzase Kant a elaborar su propia filosofía crítica. Pero se ha insistido mucho en una lectura que lo sitúa a él mismo (y a

19 Ibidem, p. 120.

20 Este es el caso, por ejemplo, de su intervención en la polémica sobre La Nueva Eloísa. Meses después, al referirse a la defensa un tanto exaltada que entonces hizo de Rousseau frente a Mendelssohn, dirá a su amigo Lindner en una carta de 4 de marzo de 1762: «Mi intención no ha sido en absoluto entrar a defender a Rousseau sino poner al descubierto la debilidad de la crítica con decoro y contundencia. Para esta tarea he necesitado una máscara y he tenido que actuar como un medio partisano del ginebrino, porque sin esta artimaña no habría podido yo jugar mi rol de modo prudente. Transeant haec- Como preludio ha estado bien y ha sido más que suficiente. El viento de Fulberto [el pseudónimo de Mendelssohn en su contrarreplica a Hamann] será un viento favorable para mi travesía; y yo ahora, como siempre, desplegaré todas las velas con toda la fuerza de mi corazón». ZH II, n² 222, 139 37, 140 1-6.

21 También aludirá a esas imágenes de modo directo en su correspondencia. Referencias a Sócrates en la misma (volumen y páginas de la ed. de ZH) : Vol I. 27; 136; 249; 275; 277; 293; 330; 341; 353; 373; $374 ; 376 ; 377 ; 398 ; 399 ; 400 ; 404 ; 408 ; 409 ; 410 ; 428 ; 429 ; 468 ;$ Vol. II 63; 68; 70; 74; 117; 118; 120; 121; $130 ; 135 ; 153 ; 165 ; 167 ; 205 ; 207 ; 214 ; 228 ; 231 ; 264 ; 266 ; 319 ; 322 ; 325 ; 334 ; 352 ; 389 ; 395 ; 410 ; 424 ;$ 491; Vol. III 12; 13; 16; 18; 19; 20; 21; 23f.; 28; 32; 34; 42; 49; 54; 67; 74; 75; 157; 180; 241; 247; 248; 259; 276; 292; 374; 381; 401; 407; 414; Vol. IV 2; 79; 84; 266; 271; 343; 351; 352; 355; 411; Vol. V 119; 184; 204; $259 ; 315 ; 331 ; 350 ; 358 ; 410 ; 456 ; 490 ;$ Vol. VI $6 ; 88 ; 148 ; 164 ; 188 ; 192 ; 195 ; 208 ; 229 ; 261 ; 263 ; 266 ; 276$; $283 ; 301 ; 329 ; 370 ; 566 ; 572 ;$ Vol. VII $168 ; 220 ; 303 ; 314 ; 322 ; 421 ; 453 ; 454 ; 475 ; 501 ; 555$. Referencias a Alcibíades en la correspondencia (ibidem): Vol. I 353; 373; 399; 428; 429; Vol. II 72; 266; Vol. III, 12; 67; 97; 135; 157; 414; Vol. IV 226; Vol. V 109; 367; 378; 453; 460; 463; Vol. VI 54; 104; 131; 147; 153; 178; 196; $257 ; 261 ; 278 ; 282 ; 283 ; 284 ; 294 ; 297 ; 299 ; 300 ; 307 ; 309 ; 317 ; 327 ; 341 ; 348 ; 355 ; 361 ; 366 ; 389 ; 395 ; 401$; 405; 441; 537;Vol. VII 17; 38; 84; 106; 116; 129; 193; 197; 232; 250; 252; 253; 254; 265; 284; 301; 317; 321; $325 ; 342 ; 344 ; 417 ; 425 ; 437$.

22 El pasaje exacto en el que aparece en la obra de 1759 el episodio de Alcibíades comparando a Sócrates con un Sileno es este: «Comparado con Jenofonte o Platón, el estilo de Sócrates debió tener quizá un aspecto más plástico — como salido del cincel de un escultor- que figurativo. Los guardianes del canon no estaban satisfechos con sus alusiones tangenciales y le reprochaban los símiles que utilizaba en sus discursos de viva voz, unas veces por demasiado rebuscadas y otras por vulgares. Sin embargo, Alcibíades comparó sus parábolas con ciertas imágenes sagradas de dioses y diosas que, según costumbre de aquel entonces, se ocultaban en un pequeño cofre o estuche en el que, cerrado, sólo se podía ver la figura de un sátiro con pies de cabra». Hamann, J. G., Sokratische Denkwürdigkeiten, N II 80 1-9. 
su Sócrates, pretendidamente cristiano) en el terreno de la religión confesional y una encubierta intención reaccionaria. Nuestra tesis, en cambio, confía en la veracidad de la afirmación que el propio Hamann hace a Lindner en una carta de 12 de octubre de 1759 y que afirma precisamente todo lo contrario a propósito de Evocación de Sócrates:

«El Sócrates cuyos hechos memorables escribo ahí fue el mayor de los cretinos en el ámbito de la teoría y el más grande sofista en el de la práctica. Sin embargo, lea usted el discurso con Alcibíades. Comprenderá entonces que ese Sócrates, y quizá algún otro también, es en realidad el portavoz desafiante de la gente sabia y sensata y la máscara de un espíritu fuerte. Mi Sócrates permanece aún como un simple pagano digno de imitación. El cristianismo habría oscurecido su esplendor. Murió como un corruptor de la juventud. El cielo nos guarde de semejante escándalo y mérito tal. Porque eso significa que no cayó en los brazos de las Escuelas ni de las prebendas; sino que mostró el camino a Alcibíades y a Platón» ${ }^{23}$.

Sócrates, el Sócrates pagano, como padre de la inversión y la verdadera filosofía, y Alcibíades como su hermeneuta, serán utilizados por Hamann como herramientas de una crítica que pretende llevar a cabo una deconstrucción de la Ilustración para hacerla ir más lejos, no para sustituir filosofía por Revelación. La influencia de Erasmo es innegable ${ }^{24}$, pero, como ya adelantamos, el filósofo alemán va a centrarse, a diferencia de él, en la crítica filosófica a toda suerte de dogmatismo y de formas culturales alienantes. Y es que el Sócrates de Hamann tiene la peculiaridad, frente al que se reivindicaba en la Ilustración, de ser un Sócrates dionisíaco, no apolíneo ${ }^{25}$. Su principal originalidad reside, pues, en servir de medio para denunciar que el contenido de la filosofía abstracta, fijada por la tradición, mecanicista y conceptual, se oponía a la vida, suplantándola mediante una realidad intermedia de vaciedades; pero no para disolver toda filosofía posible, sino para abrir paso a una nueva centrada en la creencia. Eso sí, ciertamente - hay que decirlo_ no alejada ni reñida con la verdadera religión (que él concibe igualmente ajena a dogmas, monopolios, confesiones y letra muerta).

A Hamann le interesa, pues, el Erasmo que hincó su rodilla con veneración ante un Sócrates pagano ${ }^{26}$. Y es ese elemento apolíneo el que va a utilizar en su crítica de

${ }^{23}$ Carta a Lindner de 12 de octubre de 1759. ZH I, n 163, pp. 428 34-37, 429 1-5. La cursiva es nuestra.

24 En la correspondencia de Hamann encontramos referencias a Erasmo, en ZH I 180; II 148, 344; III 6; IV 266, 32, 96; V 159; VI 566; VII 415. También se encuentran referencias a la traducción alemana por parte de Arnold de la obra de S. Knight The_Life of Erasmus, more particularly that part of it which he spent in England $<\ldots>$. Cambridge/Londres, 1726 (Das Leben des fürtrefflichen Erasmus von Rotterdam, insonderheit aber derjenige merckwürdige. Theil davon, den er in Engeland zugebracht <...>. Ins Deutsche übersetzt v. Th. Arnold. Leipzig, 1736) en las noticias de libros de sus cuadernos de estudio (Die späten Studienhefte, 11 de enero de 1781, N V 355) y en ZH IV 266. Finalmente, que en 1782 se tradujese al alemán la obra Vie de Erasme de J.L de Burigny, 2 vols, publicada en Paris, 1757, de la mano de J.Ch.F. Reichard (o Reich), Das Leben des Desiderius Erasmus von Rotterdam; aus dem Französischen des Hrn. [Jean Levésque de] von Burigny. Helmstädt, 1782, y mencionada por Hamann en V 159 y VII 415, muestra el interés por Erasmo en el contexto de la filosofía alemana del momento.

${ }_{25}$ Por ello puede afirmar M. A. Gillespies, en su obra Nihilism before Nietzsche (Chicago, University of Chicago Press, 1996, p. 241): «El concepto de dionisíaco aparece por primera vez en el s. XVIII en Heinse, Hamann y Herder». En Hamann está ya en la Evocación de Sócrates, pero se desarrolla sobre todo en su Aesthetica in nuce. Las imágenes de Dionisos y Apolo como dos tipos de belleza ideal aparecerían igualmente en la Historia del arte de la antigüedad (acabada en 1763 pero publicada en 1764) de Winckelman, posterior en todo caso a la Aesthetica in nuce de Hamann (lista en 1761 pero publicada en 1762).

${ }_{26} \mathrm{Al}$ comienzo de Sokratische Denkwürdigkeiten aparece explícita la referencia al Sócrates de Erasmo: «Así, todo un Erasmo hincó, para escarnio de muchos, su rodilla ante el sagrado Sócrates». HamanN, J. G., Sokratische..., N II 
las escolásticas y los grupos de poder ilustrados, con elementos tomados de la crítica religiosa, pero por motivos y alcances estrictamente filosóficos: su objetivo es la crítica de una cultura que considera — como después lo hará Nietzsche-decadente. Por ello está más en sintonía con la utilización que hace el erasmismo español de la imagen de la máscara, el sileno, la inversión y la perversión lingüística para la crítica filosófica, política y social que con el interés de la reforma religiosa. Un empleo de estos elementos que resulta patente, por ejemplo, en Quevedo, Cervantes o Gracián —los dos primeros, presentes en la biblioteca de Hamann, y el segundo también, a través de las obras de su mayor difusor en Alemania, Christian Thomasius- , así como en la figura, tan aludida por el Mago del Norte, del Quijote ${ }^{27}$ en cuanto Sileno verdadero. Y es que los ecos del erasmismo español llegan hasta la filosofía de Hamann y se encuentran presente en su elaboración de la metacrítica de la Ilustración.

La filosofía de Gracián y la de Hamann tienen muchos elementos en común ${ }^{28}$, dando continuidad a una presencia del primero en la filosofía alemana que comenzará con Thomasius y alcanzará su culmen en Schopenhauer ${ }^{29}$. No tenemos constancia de que Hamann leyera directamente a Gracián, aunque sí a Thomasius, fuertemente influenciado por el español, cuyo pensamiento introdujo en Alemania, quien concebía igualmente el saber como sabiduría pragmática existencial, alejada de las abstracciones, el hiperintelectualismo y la palabrería vacua característicos del saber experto y las escolásticas, considerando además obligación del filósofo liberar a los hombres de dogmatismos y ataduras abstractas. De este autor, Hamann tenía en su biblioteca Institutiones Jurisprudentia divinice (Halle, 1694), Qaestiones Historico-philosophico-juridicae (Halle, 1693), Disertationes de ratione Status, (Frankfurt, 1692), Cautelae circa praecognita Jurisprudentiae (Frankfurt, 1710) y su traducción Leben Socrates, nebst Xenophons Denkwürdigkeiten aus dem französischen des Charpentier übersetzt, von Christ. Thomas. (Halle, 1720), con la nueva edición del mismo año Der Kern wahrer und nützlicher Weltweisheit, ehedessen von Xenophon in Beschreibung der merkwürdigen Dinge des Socrates vorgestellet, und aus dem Französischen des Herrn [François] Charpentier ins Teutsche übersestzet. (Halle 1720, Neuauflage). Esta traducción (en sus dos ediciones) y los comentarios de Thomasius a las mismas constituirá una de las fuentes relevantes de su Evocación de Sócrates; aunque también recogerá en su filosofía aspectos de las otras obras de este mismo autor emparentados con el liberalismo radical.

Las ataduras abstractas a las que se refería Thomasius eran aquellas que asfixiaban y fijaban la vida bajo los conceptos, impidiéndole fluir. Y Hamann compartía desde al menos 1759 ese punto de vista: de ahí que señale el absurdo de querer derivar la existencia de un análisis conceptual. Por ello, la principal objeción que hará a la filosofía trascendental una vez que se publique la Crítica de la razón pura será precisamente que fijase las oposiciones a las que se veía abocada la razón abstracta, petrificando por tanto

${ }_{27}$ El Quijote de Cervantes figura entre sus menciones o alusiones literarias más reiteradas: así, por ejemplo, en la correspondencia, cf. ZH I (240, 440,441), II (106, 377, 442), III (17, 31, 33, 48, 65, 74, 177, $188,213,231,278,359,371,378)$, IV $(78,108,340,378)$, V (17, 66, 70, 195, 357), VI $(254,295,383,483)$, VII $(42,127,135,354,369,384,419,426,475,482,503)$.

28 Aunque muchos de ellos se encuentran igualmente presentes en el pensamiento de Vives, de quien sí sabemos, por la correspondencia con Herder, que Hamann estaba interesado en él al menos desde 1766. Carta de Hamann a Herder de 11 de febrero de 1766: «Por favor, cuando acabe usted con su Vives y no lo necesite, mándemelo, porque aquí no lo encuentro». ZH 356 8-9. Carta de Herder a Hamann de finales de marzo de 1766, p. 22, línea 33: «Le he enviado todo lo que tengo: 3 manuscritos y el Vives».

${ }_{29}$ Villacañas, J. L., "Gracián en el paisaje filosófico alemán. Una lectura desde Walter Benjamin, Arthur Schopenhauer y Hans Blumenberg». En Grande, M. y Pinilla, R. (eds.), Gracián, Barroco y modernidad. Madrid, Universidad Pontificia de Comillas, 2004, pp. 283-307. 
la labor crítica misma de la filosofía y su crecimiento vital. Para establecer entonces, bajo esas condiciones, un nuevo sistema abstracto alejado de la vida, esto es, del cuerpo, del lenguaje y de los otros: el idealismo trascendental.

A Hamann, como a Kant, le interesaba establecer como actividad prioritaria de la razón la crítica. Pero en su opinión, no era lo mismo proponerse como objetivo desenmascarar los silenos invertidos de falsa apariencia noble y racional para desautomatizar la percepción, las valoraciones, los conceptos, el lenguaje, evitando una y otra vez su fijación y abriendo un espacio a una filosofía que disolviese las oposiciones mostrándolas absurdas, que renunciar a esa tarea mediante una forma idealista de nihilismo.

\section{LA INVERSIÓN DE LOS VALORES Y LA CUESTIÓN DEL NIHILISMO}

Afirma J.R. Betz en su obra After Enligthement. The Post-Secular vision of J. G. Hamann que el nihilismo de la postmodernidad fue la otra cara y a la vez el resultado inevitable de la «razón pura» de la modernidad. ${ }^{30} \mathrm{Si}$ eso es así, cosa con la que estoy de acuerdo, el conjunto de la obra de Hamann, y en concreto su Metacrítica del purismo de la razón (1784), escrita como reacción a la Crítica de la razón pura kantiana, habría sido la primera argumentación de profundidad contra el nihilismo inherente a la razón abstracta de la modernidad.

Según el consenso establecido por los intérpretes, la cuestión del nihilismo, tal como se plantea en la filosofía contemporánea, tiene su desarrollo entre Pascal y el Existencialismo, acuñándose el uso filosófico del término en el contexto de las controversias que caracterizan el nacimiento del idealismo y expresándose por vez primera en el famoso texto de la carta de Jacobi a Fichte redactada en marzo de 1799 y publicada en otoño de ese mismo año ${ }^{31}$. Esta es la tesis, por ejemplo, de Volpi, que identifica un uso negativo y otro positivo del término en esos momentos:

«En la contraposición del idealismo al realismo y el dogmatismo, el término `nihilismo' se emplea para caracterizar la operación filosófica mediante la cual el idealismo intenta 'anular' en la reflexión el objeto del sentido común, con el fin de mostrar cómo él, en verdad, no es otra cosa que el producto de una actividad invisible e inadvertida del sujeto. Según el punto de vista, favorable o no a tal operación, el término adquiere un sentido positivo o negativo. Nihilismo significa entonces, en la acepción positiva, la destrucción de todo presupuesto y todo dato inmediato; en la negativa, por el contrario, la destrucción de las evidencias y las certezas del sentido común por parte de la especulación idealista» ${ }^{32}$.

La discusión relativa al concepto de existencia que acabaría llevando al idealismo había comenzado en Alemania en el contexto de la recepción de Hume, para el que la existencia de los objetos era indemostrable por medios abstractos y sólo podía sostenerse apoyada en la creencia. Hamann asumió como propio este punto de vista, que fue rechazado en cambio por muchos de sus contemporáneos, pues veían en el escepticismo

30 Betz, J. R., After Enligthement. The Post-Secular vision of J. G. Hamann. Oxford, Blackwell, 2008, p. 337.

31 «Verdaderamente, querido Fichte, no debo disgustarme cuando usted, o quien sea, quiere llamar quimerismo a lo que yo opongo al Idealismo, al que acuso de nihilismo». JAcoBI, F. H., Carta a Fichte de 3 de marzo de 1789. Presentación, traducción y notas de V. Serrano. En Anales del Seminario de Historia de la Filosofía 12 (1995), p. 256.

32 Volpi, F., El nihilismo. Madrid, Siruela, 2007, pp. 23 y 24. 
empirista humeano, frente a la solidez de la filosofía dogmática — fuese el materialismo francés o el espiritualismo racionalista alemán-, una forma de nihilismo, esto es, de disolución no sólo del conocimiento sino de la moral. No se usaba aún el término, pero Cousin dirá después en 1819 que el escepticismo de Locke equivalía a un nihilismo absoluto, y Hamilton en las primeras décadas del xIX ya dirá que Hume había sido «an illustrius example of Nihilism ${ }^{33}$, recogiendo en palabras nuevas lo que había sido ya un sentir respecto a ambos autores, y muy especialmente el segundo, en pleno contexto ilustrado.

La percepción de Hamann era, en cambio, precisamente la contraria: se le mostraba Hume, más allá de las apariencias, como un filósofo pleno de un sabio socratismo que dejaba espacio a una verdadera racionalidad existencial; mientras que la filosofía dogmática, fuese académica, de imprenta o de salón, le parecía un gran sileno invertido, bajo cuya apariencia de verdad — respaldada por una historiografía de la filosofía que consagraba veneraciones, supersticiones y escolasticismos- no había sino vacío ${ }^{34}$. Por decirlo brevemente, en cuanto racionalidad abstracta separada de la vida y negadora de ésta, el verdadero nihilismo estaba, para Hamann, del lado de la filosofía dogmática, en todo el espectro de sus manifestaciones.

En 1761, doce años después de la Evocación de Sócrates, obra en la que Hume, como nuevo Sócrates de su tiempo, había ocupado un lugar importante, Hamann publicó en el periódico que él dirigía en Königsberg ${ }^{35}$ un texto con el título de Reflexiones de un escéptico $^{36}$. En él desde el punto de vista de un pensador que hacía un alto en su camino, reconocía, de un lado, la soledad, el dolor y el vacío de quien, honestamente, se veía obligado a ponerlo todo en cuestión; pero de otro, la seguridad y el consuelo que ofrecía la vida no especulativa, esto es, el sentido común, el trato social, la vivencia cotidiana. Y criticando la negación de la realidad y las certezas cotidianas de un entendimiento especulativo perdido en la pedantería de un lenguaje abstracto, abogaba por una filosofía construida sobre la creencia. Si se tiene en cuenta además el comienzo muy literario del texto, en el que el filósofo confesaba sentirse un verdadero monstruo a ojos de los demás

33 Volpi, F., Op. cit., p. 24.

34 Pues a la verdadera sabiduría no se llega mediante la erudición, sino a través de la vida: «No sé ciertamente en qué consiste la erudición propiamente dicha que debo ver en el lugar señalado. Quien se representa la erudición como un panteón y sólo mira sin pestañear sus pilares hechos de imágenes e inscripciones, sin conocer y sentir el espíritu de Apolo y las nueve musas, tiene que rasgarse las vestiduras ante la creencia superior del que lo venera y el celo de sus acólitos bocazas y barrigudos, y escandalizarse tanto de las limosnas de una ignorancia ejemplar cuanto ellos mismos se cultivan con brillos externos. Desde este punto de vista han de ser entendidas todas las observaciones de los autores de la Historia de la Filosofía...». Respuesta, ensayada en borrador, a la Princesa Gallitzin a la pregunta de esta de cómo se puede alcanzar la seguridad en la Filosofía. Hamann, J.G., N II, en «Aparat», 394. El texto procede del Cuaderno de Königsberg R. II. 9. Para Hamann racionalidad es siempre racionalidad existencial y por tanto negación (irracionalidad) de la racionalidad abstracta.

35 El Königsbergsche Gelehrte und Politische Zeitungen. Publicado en Königsberg entre 1764 y al menos 1796, impreso por el editor Johann Jakob Kanter hasta ese año, y los últimos números por Nicolovius. Salía dos veces en semana, el lunes y el viernes. Para Gause, este fue "one of the most important German newspapers anywhere» (cf. Gause, F. : Die Geschichte der Stadt Königsberg in Preussen, vol. 2: Von der Königskrönung bis zum Ausbruch des ersten Weltkrieges, Köln, Böhlau Verlag, 1996, $2^{\circ}$ ed., ii.234). Sobre el periódico en sus primeros años, vid. Claudia Taszus, Die Königsbergschen Gelehrten und Politischen Zeitungen in den Jahren 1764 bis 1768. Ein Repertorium. (Luxembourg: Centre Universitaire de Luxembourg, 1998), 298 pp. La información aquí suministrada, incluidas las referencias, las tomo del trabajo S. Naragon, «18th Century German Publishers and Periodicals», en http://www.manchester.edu/ kant/helps/Periodicals.html

36 Hamann, J. G., Nachgedanken eines Zweiflers. En Königsbersche Zeitung. Beylage zum 53 Stuck. 5 de julio de 1771 y su continuación en el número 55 de 12 de julio de 1771. Cf. N IV 364-370. 
debido a su increencia intelectual, y el desarrollo posterior del mismo en el que, tras sincerarse, se descubre en su interior como el verdadero creyente en la naturaleza humana y la vida, la imagen de este socrático sileno situaba a Hamann mismo en paralelo con el Sócrates de su obra Evocación de Sócrates.

Pero las Reflexiones de un escéptico no eran más que una máscara, con la que Hamann se identificaba: la traducción de la sección VII con la que concluye el libro I del Tratado de la naturaleza humana de Hume ${ }^{37}$, suprimido un fragmento inicial que hacía mención a la parte anterior del libro y sustituida la referencia a Inglaterra por una a Alemania. Sin embargo, la mayoría de sus contemporáneos no supieron nunca que el texto en el que Hamann parecía simular un lenguaje y una actitud humeanas era en realidad punto por punto del propio Hume. No porque Hamann quisiera plagiarlo, sino porque buscaba una recepción desprejuiciada de las ideas que el texto contenía (un texto que además no representaba el aspecto exterior del pensamiento de Hume, su escepticismo, sino su interior, su existencialismo) y que coincidían con las suyas. Así, Hamann se ocultó detrás de un escrito en el que Hume a su vez se quitaba momentáneamente la máscara: un artificio indirecto para mostrar, como veremos, la clave de su crítica al nihilismo positivo. En el texto de Hume/Hamann podía leerse:

«...cuando el entendimiento actúa por sí solo y de acuerdo con sus principios más generales, se autodestruye por completo, y no deja ni el más mínimo grado de evidencia de ninguna proposición, sea de la filosofía o de la vida ordinaria» ${ }^{38}$.

En esa conclusión a su Libro I, Hume muestra la contraposición entre una racionalidad especulativa que, llevada a la producción de sistemas filosóficos dogmáticos, acaba disolviéndose finalmente o en el vacío o en la duda, y una racionalidad pragmática enraizada en la vida y en la naturaleza, sin más asiento que la creencia (belief) y la confianza. Aunque afortunadamente, afirma, las reflexiones extremadamente sutiles y refinadas de una razón especulativa que vuela sola alada por la imaginación tienen poco o ninguna influencia en el común de los hombres, por lo que ni las afirmaciones ni tampoco las dudas de los filósofos perturban mucho su vivir. Un vivir que no tiene por qué ser el subsistir embrutecido de los animales, sin ocuparse más que de la subsistencia, ni tampoco un existir amparado en la superstición (los dos peligros a los que parecía abocar el abandono de la razón abstracta, la vuelta a la animalidad o el refugio en la mala religión): de lo que se trataría más bien — dice Hume en el texto- sería de poner la racionalidad al servicio de la felicidad:

«Por consiguiente, dado que es casi imposible que, como hacen las bestias, la mente humana se limite a este estrecho círculo de objetos de que versan la conversación y la acción cotidianas, lo único que tenemos que hacer es deliberar sobre la elección de nuestra guía, y preferir la más segura y agradable. Y en este respecto, me atrevo a recomendar la filosofía, y no tengo reparo alguno en preferirla a la superstición de cualquier clase o denominación (...) si la filosofía es correcta, puede ofrecernos únicamente sentimientos serenos y moderados. Y si es falsa y extravagante, sus opiniones son objeto de una especulación fría y general, y raramente llegan a interrumpir el curso de nuestras inclinaciones naturales» ${ }^{39}$.

\footnotetext{
37 Años más tardes, Hamann traduciría también los Diálogos sobre la religión natural, publicados en inglés en 1779 y cuya traducción alemana vio la luz en 1780.

38 Hamann, J. G., Nachgedanken eines Zweiflers, N IV 366 28-30. Utilizo la traducción del fragmento de Hume al castellano realizada por Félix Duque en Hume, D., Tratado de la naturaleza humana. Introducción, traducción y notas de Duque, F. Libro I. Barcelona, Orbis, 1983. Segunda edición. Libro I, p. 420.

39 Hamann, J.G., Nachgedanken ..., N V 369 31-42. Hume, D. : Op. cit., pp. 424-425.
} 
Hamann utilizó el texto de Hume en un momento en que reavivaba en Alemania la polémica sobre la cuestión del escepticismo a partir de la aparición en Inglaterra del libro de James Beattie An Essay on the Nature and Immutability of Truth in Opposition to Sophistry and Scepticism, obra que atacaba directamente la filosofía de Hume y publicada en Edimburgo en 1770, de la que no se contaría con traducción alemana hasta que no apareció Versuch über die Natur und Unveränderlichkeit der Wahrheit im Gegensatz. der Klügeley und Zweifelsucht, a su vez publicada en Copenhague y Leipzig en 1772, si bien se le hizo ya una reseña a comienzos del año 1771 en el Göttingische Anzeigen von gelehrten Sachen ( $n^{\circ} .12,28$ de enero $)^{40}$.

Unos meses después de esta reseña ${ }^{41}$, Hamann buscó el efecto de adaptar a Alemania lo dicho por el filósofo inglés, asumiendo su mismo punto de vista para terciar en la polémica y seleccionando para ello un parágrafo del Treatise en cuyo fragmento inicial se exponía cierta situación que bien podía aplicársele a él mismo en lo que respecta a su rechazo escéptico a la filosofía académica (por su vaciedad y su alejamiento de la vida) y a la superstición de la mala religión, y que tenía, como hemos dicho, un talante socrático que hacía de Hume un nuevo sileno verdadero con el que él mismo se identificaba.

Suprimidas las primeras líneas iniciales, el texto publicado comenzaba directamente con la confesión existencial:

«Me siento como alguien que, habiendo embarrancado en los escollos y escapado con grandes apuros del naufragio gracias a haber logrado atravesar un angosto y difícil paso, tiene sin embargo la temeridad de lanzarse al mar en la misma embarcación agrietada y batida por las olas, y lleva además tan lejos su ambición que piensa dar la vuelta al mundo bajo estas poco ventajosas circunstancias. La memoria que guardo de errores y confusiones pasadas me hacen desconfiar del futuro. La mezquina condición, debilidad y desorden de las facultades que debo emplear en mis investigaciones aumentan mi aprensión. Y la imposibilidad de enmendar o corregir estas facultades me reduce casi a la desesperación, y me conduce más a quedarme a morir en la estéril roca en que ahora me encuentro que a aventurarme por ese océano ilimitado que se pierde en la inmensidad.» ${ }^{42}$.

Una imagen similar a esta acabaría apareciendo en la Crítica de la razón pura de la mano de Kant, probablemente inspirado por la versión hamaniana ${ }^{43}$. Pero es el párrafo segundo de Reflexiones de un escéptico el que nos interesa:

«En primer lugar, me siento asustado y confundido por la desamparada soledad en que me encuentro con mi filosofía; me figuro ser algún extraño monstruo salvaje que, incapaz de mezclarse con los demás y unirse a la sociedad, ha sido expulsado de todo contacto con los hombres, y dejado en absoluto abandono y desconsuelo. De buena gana correría hacia la multitud en busca de refugio y calor, pero no puedo atreverme a mezclarme entre los hombres teniendo tanta deformidad. Llamo a otros para que se

40 A la primera reseña en Alemania de la obra inglesa que apareció en el Göttingische Anzeigen von gelehrten Sachen, 1771, no. 12 (28 de enero), pp. 91-96, le seguirían otras dos reseñas más en 1772 y 1776, la primera en el Frankfurter Gelehrte Anzeigen LXXXIV (21 de octubre 1772), pp. 665-669 y LXXX (23 de octubre de1772), pp. 673-677, cuyo autor era Herder; y la segunda en 1776 en la Allgemeine deutsche Bibliothek, en los suplementos a los volúmenes 13-24, 3 vols., pp. 497-503.

${ }^{41}$ No sabemos si para entonces Hamann había leído ya en inglés el libro de Beattie, cosa habitual en él (leer los libros ingleses recién publicados), o si esperó a leerlo en la traducción alemana (lo que sería raro). En todo caso, sí sabemos que la leyó según consta en la cara a Herder de 5 de agosto de 1781, y también la reseña que éste le hizo. Cf. ZH III 13, 75 IV 317. Kant citaría después también a Beattie en sus Prolegómenos.

42 Hamann, J. G., Nachgedanken ..., N V 364 1-15. D. Hume: Op. cit., pp. 414-415.

43 Kant, I., $K r V$ A 235-6 B 294-5. 
me unan y nos hagamos así compañía aparte de los demás, pero nadie me escucha. Todo el mundo permanece a distancia, temiendo la tormenta que cae sobre mí en todas partes. Me he expuesto a la enemistad de los metafísicos, lógicos, matemáticos y hasta teólogos: ¿podría extrañarme entonces de los insultos que debo recibir? He dicho que desaprobaba sus sistemas: ¿deberé extrañarme entonces de que ellos odien el mío y también a mi persona? Cuando miro a mi alrededor presiento por todas partes disputas, contradicciones, ira, calumnia y difamación. Cuando dirijo la vista a mi interior, no encuentro sino duda e ignorancia.» ${ }^{44}$

Esta imagen del filósofo que en su apariencia externa parece ser un monstruo al poner en cuestión el saber establecido, pero que en su interior se encuentra dotado de la belleza del sentido común, y que si bien reconoce la duda y la ignorancia, no por eso deja de dar espacio a la sabiduría existencial, debió gustarle mucho a Hamann, pues se encuentra en el marco de sus instrumentos críticos favoritos. La cuestión de que la sabiduría de los sabios, vista desde el pueblo, no es más que locura, de la inversión de valores que acontece en la filosofía académica ${ }^{45}$, es una constante en las obras del filósofo alemán. Y aparece igualmente centrada, como en Hume, en una crítica al lenguaje experto.

Así, en Brocken, la colección de reflexiones escritas por Hamann entre 1758 y 1759 , consideraba ya, de un lado, que sólo hay sabiduría — sólo queda libre la sabiduría - en la contradicción, es decir, allí donde se niegan e invierten los valores y las apariencias, donde se identifican y deconstruyen los sistemas de oposiciones; y de otro, que la verdadera sabiduría que se libera con ello no es conceptual: es sensación física, esto es, conocimiento inmediato, instinto. Pues para Hamann, la verdadera sabiduría es creencia, y la creencia es un conocimiento desde las entrañas ${ }^{46}$.

La filosofía ha de tener, por tanto, siempre un momento negativo. La hermenéutica de toda crítica filosófica debía ser, según Hamann, la de la sospecha, invirtiendo toda apariencia sistemáticamente para liberar el contenido oculto; volviendo a continuación a desenmascararlo, para subvertir de nuevo a éste como mera apariencia y seguir sospechando. Sin embargo para él esa labor no era una forma nihilista de pensamiento destructivo, sino la única forma de autenticidad y de autoconocimiento. Por eso, la labor de todo pedagogo de la libertad que quisiese llevar a sus discípulos (o a la opinión pública) a pensar por sí mismos había de ser, en su opinión, la de constituirse él mismo en un conjunto de máscaras superpuestas que obligasen al que se forma a ir cambiando a su vez de punto de vista con el fin de aprender ese método de transvaloración. Y fue esto lo que él hizo a través de su periódico, desde el que reseñó, criticó, parodió, subvirtió e incluso homenajeó enmascarado al pensamiento de la época en todas sus variantes.

Para Hamann la figura de Sócrates, tal como él la concebía, era el ejemplo vivo de esta pedagogía de apertura de los silenos que no es conocimiento del mundo sino conocimiento de uno mismo. De ahí su interpretación del escepticismo como una filosofía revitalizadora, frente a una filosofía muerta, escolástica, apegada a la letra y al poder y consagrada por una historiografía servil. Pero un escepticismo entendido como nihilismo metódico que se muestra, si se desentraña, vía única al conocimiento de sí mismo, a la creencia y a la piedad; y que deja al descubierto al verdadero nihilismo decadente,

44 Hamann, J. G., Nachgedanken ..., N V 364 20-35. D. Hume: Op. cit., pp. 416-417.

45 Cf., por ejemplo, Hamann, J. G., Wolken, N II 108, 19-26.

46 «La creencia no es un producto de la razón y no puede por ello erradicarse mediante ataque alguno de la misma; porque creer se deriva tan poco de argumentos como ver o saborear». HAMANN, J. G., Sokratische Denkwürdigkeinten, N II 74 2-5. 
que es para Hamann abstracción, negación de la vida, castigo y olvido del cuerpo, solipsismo.

Kant también consideraría el escepticismo como un paso importante e ineludible hacia la verdadera filosofía crítica. Y aunque elaboraría la cuestión de la creencia de un modo muy diferente a Hamann, según analizaremos más adelante, arremetería igualmente contra la hipocresía de los que se escandalizaban de las tesis de Hume, al que trató con mucho respeto ${ }^{47}$, viendo en la demolición una oportunidad para construir:

«Si preguntáramos al impasible Hume, hombre realmente cualificado para el equilibrio del juicio, qué fue lo que le movió a socavar, a base de laboriosas y sutiles reflexiones, la convicción, tan confortadora y útil a los hombres, de que su conocimiento racional bastaba para afirmar y obtener un concepto determinado de un ser supremo, respondería: únicamente el propósito de hacer avanzar la razón en el camino de su autoconocimiento, a la vez que cierto enojo ante la coerción que se pretende ejercer sobre la razón, en el sentido de que se presume de sus posibilidades al tiempo que se le impide declarar libremente sus debilidades, las cuales se revelan de forma patente cuando se examinan (...) ¿Qué hacer, pues, especialmente ante el peligro que parece amenazar con ello al bien público? Nada es más natural, nada más justo, que la decisión a tomar a ese respecto. Dejad que esa gente siga su camino. Si son personas de talento; si presentan una investigación profunda y nueva; en una palabra, si muestran simplemente razón, ésta sale ganado en todo caso. Si acudís a medios distintos de los de una razón libre de presiones; si gritáis que se comete alta traición; si llamáis a la gente —que no entiende de elaboraciones tan sutiles- como si se tratara de apagar un fuego, os ponéis en ridículo. En efecto, la cuestión no es, en estos casos, qué sea lo ventajoso o desventajoso al bien supremo de la comunidad, sino simplemente hasta dónde puede llegar la razón en su especulación, prescindiendo de todo interés, y si puede contarse con tal especulación para algo o es preferible abandonarla en favor de lo práctico (...) A la razón le hace mucha falta esa lucha. Ojalá se hubiese desarrollado antes y con ilimitada y pública autorización. Tanto más pronto hubiese surgido la crítica, ante la cual tienen que desaparecer todas esas disputas... ${ }^{48}$

Y es que Kant consideraba que, si bien la hipocresía y la simulación pudieron contribuir en un momento histórico a la civilización del hombre, estas no debían seguir manteniéndose, y desde luengo nunca sostenerlas en el plano intelectual. Es más, en su opinión, plantear dudas de modo radical no tenía necesariamente por qué atentar contra el bien público, y por ello arremete contra los que se escandalizaban ante lo que en la época se llamaba (y Hamann usará la expresión) espíritus fuertes, considerando contraproducente el fingimiento para tapar los flancos débiles de la razón, el conocimiento y la fundamentación de la moral. Antes bien, la razón humana no debería — dice- conocer más juez que la razón humana, y de ahí que sea útil para su avance que ella misma se someta a autocrítica.

«Hay cierta falta de nitidez en la naturaleza humana, falta que, en definitiva, como todo cuanto procede de la naturaleza, ha de orientarse hacia fines buenos. Se trata de una tendencia a disimular las verdaderas intenciones y a mostrar ficticiamente otras que consideramos buenas y honrosas. Con toda seguridad, esa inclinación humana, tanto a disimular como a adoptar una apariencia ventajosa, no sólo ha civilizado al hombre, sino que, hasta cierto punto lo ha ido moralizando. En efecto, al no poder ver nadie a través de la máscara de respetabilidad, honorabilidad y honestidad, cada uno encontraba en los ejemplos, presuntamente sinceros, que veía en derredor suyo, una

47 «...Hume, autor intachable por su carácter moral y de sentimientos no menos sanos». KANT, I., $K r V$ A 746 B 774. Cito la $K r V$ siguiendo la traducción de Pedro Ribas.

48 Kant, I., $K r V$ A 745-747 B 773-775. 
escuela de perfección para sí mismo. Pero dicha inclinación a presentarse mejor de lo que se es y a manifestar intenciones que no se tienen, sólo provisionalmente, por así decirlo, sirve para sacar al hombre de la grosería y para hacerle adoptar, por de pronto, las maneras de lo bueno, pues, más tarde, cuando ya los verdaderos principios han sido desarrollados y han pasado a formar parte del modo de pensar, esa ficción han de ser progresivamente combatida con dureza. De lo contrario, pervierte el corazón e impide que las buenas intenciones crezcan entre las hierbas de las bellas apariencias.

Me duele observar la misma falta de nitidez, el mismo disimulo e hipocresía, incluso en las manifestaciones del pensamiento, donde ello no reporta ningún beneficio y donde se encuentran muchos menos obstáculos para revelar el propio pensamiento franca y abiertamente, como es debido. En efecto ¿qué puede causar más perjuicio al conocimiento que el hecho de que hasta los simples pensamientos que se comunican sean falsos, que el disimular las dudas que nuestras propias afirmaciones nos inspiran, que el presentar como evidentes los argumentos que no nos satisfacen ni a nosotros mismos?(...) Cuando la colectividad considera que los sutiles sofistas tratan nada menos que de hacer tambalear los cimientos del bienestar público, no sólo parece sensato, sino permisible y hasta muy meritorio, contribuir a la buena causa con fundamentos aparentes, antes que dejar a los supuestos adversarios de la misma la ventaja de reducir nuestro tono a la moderación de una mera convicción práctica y antes de que nos obliguen a confesar nuestra falta de certeza especulativa y apodíctica. Debería, sin embargo, pensar que nada hay en el mundo más incompatible con el propósito de afirmar una buena causa como la perfidia, el disimulo y el engaño» ${ }^{49}$.

Ahora bien, aunque estos textos de Kant a los que nos venimos refiriendo sean de la Crítica de la razón pura y se publicasen por tanto en 1781, reflejan bien las inquietudes de este filósofo en el periodo precrítico a partir de 1760, y por eso se encuentran en la parte de esa obra en la que recapitula cómo ha quedado la cuestión del escepticismo y el dogmatismo una vez fundada la filosofía crítica, refiriéndose explícitamente a Hume en términos positivos en su intención. Y aunque pueda señalar ya sus errores, reconocerá sus méritos, distinguiendo al escéptico del sofista dogmático:

«El escéptico es, pues, el educador del sofista dogmático, el cual es inducido a efectuar una sana crítica del entendimiento y de la razón misma. Una vez realizada esta crítica, no tiene por qué temer impugnaciones, puesto que desde ella distingue lo que posee de lo que se halla totalmente fuera de su posesión; esto último ya no es reclamado por él, ni puede enredarse en disputas acerca de ello. El método escéptico no es, por tanto, satisfactorio en sí mismo en relación con las cuestiones planteadas por la razón, pero sí es instructivo en orden a despertar en ella la cautela y a indicarle cuáles son los medios adecuados para asegurar su legítima posesión». ${ }^{50}$

Kant recibió influencia de Hamann/Hume ${ }^{51}$ en dos fases. Una primera, entre la publicación de Evocación de Sócrates (a partir de la cual comienza a problematizar ya el

49 KANT, I., $K r V$ A 748-749 B 776-777.

50 Kant, I., $K r V$ A 769 B 797.

51 El interés por Hume en Alemania no comenzó a extenderse sino a partir de 1750, pues hasta esa fecha los prejuicios teológicos habían obstaculizado la recepción, ya que su empirismo era considerado un primer paso hacía el escepticismo y este último a su vez la demolición de la religión. A partir de ese momento, en cambio, con el declinar de la escuela leibno-wolffiana, la Ilustración alemana dio un giro hacia la recepción de ideas nuevas. Y en esto último la mano de Hamann, uno de los pocos que leía las obras de Hume en las ediciones originales, fue decisiva. En una fecha tan temprana como 1756 -antes de su viaje a Inglaterra, por tanto- Hamann ya exponía a Lindner que su libertad intelectual iba estrechamente vinculada a su escepticismo y que leía a Hume, tomando distancia de los wolffianos: «Para un wolffiano, nunca se es lo suficientemente ecléctico, pero para un espíritu libre, nunca se es lo suficientemente escéptico» (Carta a Lindner de 1 de junio de 1756. ZH I n 78205 30-32. En 1755, en otra carta a Lindner de 28 de mayo había aparecido la primera referencia a Hume en la correspondencia). 
concepto de existencia y a abordar la cuestión de la creencia) y 1771, compartiendo durante ella muchos de los puntos de vista de su amigo. De hecho, la forma expositiva de los Sueños de un visionario y su propio contenido, que tras la radical crítica inicial, acaba salvando al final a la creencia y la esperanza, tienen muchos elementos, en el estilo, de las obras de Hamann, y una gran influencia tanto de Hume como de Hamann mismo en su contenido. Pero con la publicación de la Dissertatio, ambos filósofos comenzaron a divergir en dos línea filosóficas nuevas e irreconciliables.

En una segunda fase, la comprendida entre 1771 y 1781, la influencia de Hume se elevó de grado, y con ella también la elaboración de Kant de la cuestión del escepticismo. Con la Crítica de la razón pura los caminos los dos filósofos alemanes se separaron radicalmente, a pesar de seguir siendo amigos: donde Kant veía una solución que conciliaba escepticismo y creencia, salvando las escisiones que atravesaban la filosofía ilustrada y en general al conjunto de la filosofía del siglo xvIII, Hamann comprendió que se consolidaba y reforzaba el nihilismo moderno mediante una nueva forma del mismo: el idealista. Y así, un teólogo próximo a él, Daniel Jenisch acabaría advirtiendo de que la negación idealista de las cosas implícita en la filosofía kantiana constituía de hecho «ateísmo y nihilismo».

Jenich, en su tratado Sobre el fundamento y el valor de los descubrimientos del señor Kant en metafísica, moral y estética (presentado al premio de la Academia Prusiana de Ciencias en 1796), contraponía al dogmatismo y al realismo la filosofía de Kant, que si bien tenía aspectos positivos, podía ser interpretada también como el más manifiesto ateísmo y nihilismo en cuanto sumía en la irrealidad a toda la naturaleza y sus miríadas de criaturas $^{52}$. Por ello Hamann, además de seguir ejerciendo la crítica de la filosofía ilustrada, había tenido además que centrarse, a partir de la de 1781, en la metacrítica del purismo de la razón de Kant. Se iniciaba la vía que llevaría a Jacobi, formulándose la cuestión del nihilismo en términos plenamente filosóficos en la carta a Fichte ya referida.

Así que a partir de 1781 y hasta su muerte en 1788, Hamann reelaboró su pensamiento ahora ya no contra el enciclopedismo francés o el racionalismo alemán, sino contra Kant, a pesar de que nunca dejó de mantener una estrecha amistad con él, buen ejemplo de sus propias teorías acerca de la razón abstracta y los afectos. En la Metacrítica del purismo de la razón afinó ya una crítica al idealismo trascendental como filosofía que nacía muerta por su distanciamiento de la realidad: un nuevo sistema conceptual que venía a rearmar y a consolidar la razón hipocondríaca de los ilustrados. Esa razón escrupulosa que buscaba eliminar cualquier contaminación con la irracionalidad, el cuerpo, los sentimientos, las creencias y la vida y que establecía una tutela restrictiva a la tolerancia.

Pero entre 1781 y 1788 Alemania conocería además otra polémica que sería esencial para la cuestión que venimos abordando. En 1785 Jacobi publicaba su correspondencia con Moses Mendelssohn acerca de la naturaleza de la filosofía en general y del spinozismo en particular, en la que, como había hecho ya antes Hamann, aunque de una forma diferente, cuestionaba los valores y el nuevo humanismo patrocinados por la corriente hegemónica de la Ilustración: Cartas a Moisés Mendelssohn acerca de la doctrina de Spinoza. En 1787 incluyó en su obra David Hume acerca de la creencia, o Idealismo

\footnotetext{
Sobre la recepción de Hume en Alemania, cf. el trabajo clásico de Gawlick, G. y KreimendHal, L. Hume in der Deutschen Aufklärung. Suttgart-Bad Cannsatatt, Frommann-Holzboog, 1987. Sobre la recepción de Hume por parte de Kant, además de las interpretaciones clásicas de Fischer, K., Vaininger, H., Paulsen, F., Adickes, E. o Künh, M., entre otros, cf. Paul Guyer: Knowledge, Reason and Taste: Kant's Response to Hume. Princeton, Princeton UP, 2008.

52 JenIsch, D., Über Grund und Wert der Entdeckungen des Herrn Professor Kant in der Mataphysik, Moral und Ásthetik, 1796. Cit. en Pöggeler, O., "Hegel und die Anfange der Nihilismus». En Continental Philosophy Review, vol. 3, n 3 (1070), pp. 163-199.
} 
y Realismo. Un diálogo, en la que se defendía de la acusación de irracionalismo por el uso que había hecho del concepto de creencia, un apéndice que criticaba duramente el idealismo trascendental, coincidente con la publicación ese mismo año de la segunda edición de la Crítica de la razón pura. En 1789, en la segunda edición de la correspondencia con Mendelssohn, incluiría también sus reflexiones sobre la publicación de la Crítica de la razón práctica de Kant el año anterior.

Sin embargo Hamann, que había mantenido correspondencia con Jacobi a propósito de la cuestión de la creencia y había seguido la polémica a esta fecha, no pudo ya leer los nuevos textos de este último porque falleció en el mismo 1788.

\section{Nihilismo y humanismo}

El concepto de nihilismo puede entenderse, pues, por lo que hemos ido exponiendo, en dos sentidos diferentes: de un lado, hace referencia a la negación de la realidad del objeto del conocimiento, viendo en el mismo un producto de la actividad del sujeto, y a todas las consecuencias de esa negación, en el marco del idealismo; pero de un modo más amplio se refiere a toda negación de alguno de los aspectos de la vida, y los valores de la misma, por parte de la razón abstracta o sus construcciones culturales.

Entendido en el primer sentido, la inicial reacción contra el nihilismo fue la que se conoció en el contexto de la formación del idealismo alemán - y que recibió su pionera formulación frente al idealismo trascendental—- presentando al principio características sobre todo religiosas, en cuanto se lo valora como una forma de ateísmo, para pasar a ser formulada después en términos filosóficos: el mejor representante de esa primera reacción es Jacobi. Pero si se utiliza el término nihilismo en su segunda acepción, que será la que históricamente gozará de más continuidad hasta nuestros días y de la que la primera se muestra como la concreción de una de sus formulaciones en un momento histórico dado, la denuncia de la suplantación de la vida por parte de la razón abstracta y sus construcciones culturales se remonta a Erasmo, aparece de nuevo en Gracián, el joven Burke y Rousseau, entre otros, y se encuentra magistralmente desarrollada en todo su alcance por Hamann. Quien, al caminar en paralelo con Kant, realiza el tránsito de la forma característica de plantear el problema en la primera modernidad al modo de hacerlo la modernidad tardía o contemporaneidad. De Hamann surgirá la deriva hacia Herder y el Romanticismo.

Cuando en Alemania los filósofos protoidealistas y la reacción a los mismos estén configurando, unos, la nueva forma histórica que adoptará la razón abstracta, y otros, su artillería contranihilista (centrando la cuestión en el primer sentido del término nihilismo arriba mencionado), Herder y Paine estarán extrayendo y denunciando las consecuencias políticas antihumanistas de la razón abstracta ilustrada en la misma dirección que Hamann, como se evidencia de un modo nítido en la polémica que Paine sostiene con Burke a propósito de la Revolución Francesa y la relación que ambos establecen entre razón abstracta y violencia ${ }^{53}$.

En el contexto del idealismo, la polémica en relación al nihilismo quedó centrada esencialmente en sus inicios en el problema de la posibilidad o imposibilidad de demostrar la

53 Cf. CAnterla, C., "Violencia, terror y poder razonable en Burke, Paine y Herder», en Daimon. Revista Internacional de Filosofía 47 (2009), pp. 7-25; "La enfermedad del filósofo: la crítica a la razón abstracta a propósito de la Revolución Francesa», en LóPez SASTRE, G. y SANFÉLIX, V., Nacionalismo y cosmopolitismo. De la Ilustración al mundo contemporáneo. Valencia, Universidad de Valencia-Museu Valencià de l’Il.lustració i la Modernitat, 2010, pp. 137-154. 
existencia autosuficiente de los objetos y el mundo, y fue por tanto ante todo una discusión relativa a un nihilismo epistemológico y sus consecuencias ontológicas y teológicas, aunque obviamente también axiológicas ${ }^{54}$, en la que la crítica a la tradición y a la cultura, así como sus consecuencias para la libertad y la dignidad del hombre, no estaba tan presente. En cambio en Hamann era esta última cuestión la importante, por cuanto su objeción a la filosofía abstracta y erudita tendrá como objetivo denunciar su negación de los valores de la vida y la suplantación que hace de esta por un mundo intermedio de teoría que violenta a los seres humanos. La diana de su denuncia es, pues, un nihilismo axiológico tanto moral como político y las bases en que este se sustenta, mostrándose el nihilismo epistémico instrumento y justificación, más que causa inocente, del primero.

Tres años antes de la Evocación de Sócrates de 1759, en un breve texto suyo que publicó como anexo a una traducción que hizo de un libro de economía, ${ }^{55}$ Hamann había llamado la atención acerca de la homología que él observaba entre la forma de estructurarse las relaciones económicas en una nación y la configuración que adoptaban en la misma el aparato intelectual, las relaciones sociales y la política, y en concreto hacía reparar en la relación existente entre dogmatismo, sectas filosóficas y dominación. La obra traducida, aunque se atribuía a Dangeuil ${ }^{56}$ por muchos contemporáneos, era en realidad - y Hamann lo sabía - del economista inglés Josiah Tucker (citado después elogiosamente por Marx en El Capital) y los intérpretes consideran el apéndice hamaniano un anticipo de las ideas de Adam Smith, Hegel y Marx.

En el Beilage - una embrionaria filosofía de la historia- Hamann contraponía el viejo mundo a la modernidad, realizando a propósito de ello sus primeras afirmaciones radicales respecto a la falsa filosofía caduca, con sus monopolios dogmáticos, y la nueva filosofía que era precisa. Citaba a la antigua gran potencia España como modelo de nación decadente debido a una economía basada en la rapiña de materias primas y el control estatal de los monopolios comerciales; organización económica que llevaba aparejada además como reflejo suyo una administración centralizada del monopolio de la verdad -manifiesta en la organización escolástica de la filosofía, dedicada a construir imponentes castillos metafísicos ${ }^{57}$ - y la concentración de los bienes en un solo grupo social, la aristocracia. Viejo mundo frente al cual el joven Hamann situaba a las que él consideraba nuevas naciones en auge, Holanda e Inglaterra, sociedades con una economía basada en el libre comercio que tenían como reflejo un sistema intelectual basado en la tolerancia y la libre circulación de ideas, y un nuevo grupo o clase ${ }^{58}$ social, la burguesía mercantil, que él consideraba ingenuamente transversal. Hamann consideraba

54 El mismo Heidegger describió al nihilismo como el estado en el que no queda nada del ser en sí, argumentando que el nihilismo se apoya en el reduccionismo del Ser a un mero valor. Cf. HeIDEgGER, M. Carta sobre el Humanismo. Madrid, Alianza Editorial, 2004.

55 El conocido como Beilage zu Dangeuil, su apéndice a Des Herrn von Dangeuil's Anmerkungen über die Vortheile und Nachtheile von Frankreich und Großbritannien in Ansehung des Handels und der übrigen Quellen von der Macht der Staaten; nebst einem Auszuge eines Werkes über die Wiederherstellung der Manufakturen und des Handels in Spanien. En 1756 se publicaron ediciones en Mitau (es el ejemplar que Hamann tiene en su biblioteca) y Königsberg (el que tiene Lindner en la suya), y en 1757 en Danzing y Leipzig, en la casa editorial de Johann Chri. Schuster. El apéndice que Hamann incluyó en esta traducción está en N IV 225-242.

56 Louis-Joseph Plumard de Dangeuil era solo su traductor francés, pero le había añadido también sus propios comentarios.

57 Hamann, J. G., Beilage zu Dangeuil, N IV 232.

58 El texto alemán de Hamann dice literalmente «Kaufleute», pero ya una traducción de HedGE, F. D. al inglés del Beilage en 1847 (Prose Writers of German, Philadelphia, Carey and Hart) utiliza la expresión «mercantile class» (p. 124). Empleo aquí este término (clase) que se ha consolidado en los traductores de Hamann a propósito de este texto. 
que el libre comercio, la libre difusión de las ideas sin control dogmático de ninguna índole y la igualdad de oportunidades nivelaría las clases sociales y socializaría el bienestar y la libertad en una meritocracia.

El joven Hamann deseaba que Alemania se pareciese a Holanda o Inglaterra, no a España. Pero el panorama que la filosofía presentaba en su país era lo más parecido, a sus ojos, a una sociedad con un control estatal del monopolio de la verdad. Y aunque acabaría decepcionándose muy pronto del papel emancipador que había otorgado a la burguesía y al libre comercio, una gran parte del diagnóstico que había hecho en su breve apéndice sobre la filosofía lo mantendría hasta el final de sus días, denunciando a lo largo de sus obras la relación existente entre el dogmatismo filosófico y los obstáculos a la emancipación. Para señalar además la complicidad con el poder político —erigiéndose en falsos tutores de lo racional- por parte de academias, universidades y una nueva casta de asesores y expertos políticos, menos interesados en extender las luces y la libertad al pueblo que en favorecer el enriquecimiento de unos cuantos. De ahí que después dijese en la Evocación a Sócrates:

«(...) la sabiduría seguirá siendo el secreto mejor guardado de la política mientras que esta no tenga otro objetivo, como la alquimia, que el enriquecimiento (...). Según el presente orden del mundo, el arte de hacer oro es ciertamente el proyecto más elevado y el bien más preciado que compete a nuestros gobernantes.» ${ }^{59}$

Hamann había escrito ya en su Beilage que la filosofía debía dejar de ser mera estatuaria $^{60}$ (lo que Nietzsche llamaría más tarde historia anticuaria) para convertirse en una sabiduría viva que sacase a los eruditos de las bibliotecas y los introdujese en el torrente de la vida. Por eso le diría tres años más tarde a Kant en una carta: «Si quiere enseñar filosofía a esos chicos, déjese de erudición: iponga corazón!. Vale et sapere AUDE!» ${ }^{61}$. Bajo las diversas máscaras de la verdad abstracta no había, en su opinión, más que vacío, y así se lo había dicho también a su amigo en otra carta del mismo año 1759, utilizando la imagen de un poema popular:

«Como la verdad, para protegerse de ser asaltada en la calle, se embozó con tanto traje superpuesto, acabó por dudarse que tuviese cuerpo. ¡Cuál no sería el horror al ir a desnudarla: vieron ante sí la verdad, un espectro! ! ${ }^{62}$.

La nueva filosofía debía abandonar la erudición y el dogmatismo para pasar a ser, en su opinión, una filosofía dionisíaca ${ }^{63}$ que, adoptando una forma contracultural, liberase al hombre de la alienación, la enfermedad y la decadencia. De ahí que se enfadase tanto más tarde cuando Kant publicara su artículo ¿Qué es la Ilustración?, en el que la divisa hamaniana ilustrada ( «Sé fuerte y atrévete a saber») quedaba amputada legitimando el

59 N II 4-60.

60 «La filosofía no es ya una estatuaria. El erudito debe apartar sus ojos de los castillos españoles del mundo intelectual y de las sombras de la bibliotecas para dirigirse al gran teatro de la naturaleza y sus hechos, para volverse al arte de vivir...». Hamann, J. G., Beilage zu Dangeuil, N IV 232 17-20. La imagen según la cual la filosofía ha sido una disciplina coleccionista de bustos de hombres ilustres del pasado se repite a menudo en la obra de Hamann.

61 ZH I n ${ }^{\circ} 168446$ 2-3.

62 Hamann, J. G., Carta a Kant de 27 de julio de 1759. ZH I n 153, 381 8-11.

63 «La naturaleza actúa a través de los sentidos y las pasiones. Quien mutila sus herramientas ¿cómo podría sentirla? ¿Pueden unos nervios paralizados ponerse en movimiento? Vuestra filosofía mortalmente engañosa ha despachado a la naturaleza: ¿por qué entonces queréis que la imitemos? Con ello no podéis sino renovar el goce de convertiros en asesinos junto a los discípulos (...) ¡Sí, vosotros, delicados jueces del arte!». J. G. Hamann: Aesthetica in nuce N II 206 1-7. "Así pues, no os aventuréis en la metafísica de las bellas artes sin haberos perfeccionado antes en orgías y misterios eleúsicos». N II 201 11-13. 
sometimiento $^{64}$. Pues durante los años intermedios a esas dos fechas, 1756 y 1784, Hamann había dedicado sus esfuerzos, situándose en posiciones de un liberalismo radical, a mostrar las trampas de la emancipación lisiada que proponían muchos ilustrados, que justificaban el sometimiento apelando a un poder razonable que tutelase a aquellos colectivos humanos que, como las mujeres, los negros o los desprovistos de recursos, se considerasen inmersos aún en la animalidad ${ }^{65}$. Y Kant se alineaba de nuevo en su escrito con los falsos tutores.

La cuestión que Hamann estaba denunciando - las consecuencias negativas para la vida de un grupo muy amplio de los seres humanos de la filosofía canónica de la Ilustración- no era un tema circunstancial. Como después mostrarían los hechos, el nihilismo y la política de la modernidad estaban desgraciadamente estrechamente relacionados con la violencia. Así, Pöggeler, afirmaría en 1970 que los abismos a los que había llegado la política en el siglo xx - y no sólo en el siglo xx, sino ya en el xIx, como muy bien señalara Hanna Arendt - no habían sido otros que los abiertos por el nihilismo ${ }^{66}$ : la supresión de toda distinción entre un animal y un humano. Pero para indicar los lazos que unen nihilismo y antihumanismo (o mejor, contra-humanismo) hay que arrojar más luz sobre el término en sí y su uso en la filosofía.

Para Hamann nihilismo (no usa aún el significante de la palabra, pero tiene ya el significado, el concepto y el diagnóstico: el nihilismo de la razón abstracta y pura es para él un escrupuloso purismo hipocondríaco) es aquella patología que padece toda forma de construcción cultural que se constituye en negación y suplantación de la vida, y que lleva a los seres humanos a la enfermedad —incluida la melancolía y el pesimismo existenciales según los cuales la vida no tiene sentido-, la miseria y la desgracia. Toda crítica que deje al descubierto esta situación es contranihilista, pero resulta en cambio, paradójicamente y por el problema ya aludido de las inversiones, recibida y denunciada en el momento histórico en el que se ejerce como si ella misma constituyese una forma de disolución antihumanista de los valores.

Así, hay que distinguir igualmente desde la perspectiva axiológica, como ya hicimos en el nihilismo epistémico, entre nihilismo positivo y negativo, esto es, entre un nihilismo axiológico positivo contrahumanista, aparentemente espiritualizador pero en realidad destructor de los valores ligados al cuerpo y a la biología, a los que sustituye por conceptos decandentes que niegan el sentido común y avalan las relaciones de poder y la sumisión de unos hombres por otros mediante una filosofía abstracta y muerta; y un nihilismo axiológico negativo que aparentemente es disolvente (pone en cuestión los valores sociales y culturales del nihilismo positivo) pero que en realidad es una liberación para el hombre y una oportunidad para la construcción de la nueva filosofía y un nuevo humanismo.

Esta cuestión de la fundamentación de todo humanismo posible se ha planteado de modo radical en los últimos setenta años y llega hasta nuestros días, y los intérpretes han vuelto por ello a interesarse de nuevo por Hamann. Ya en los años cuarenta,

${ }^{64}$ Como le diría a Strauss en una carta, en su escrito Kant excluía de la ilustración a la mitad del género humano, las mujeres, legitimaba la censura y autocensura de los funcionarios bajo un régimen político despótico y opresor, y atribuía a los dominados la culpabilidad de su estado en vez de denunciar la de los tutores empeñados en mantenerlos bajo dominación: «La verdadera Ilustración consiste en la liberación de la persona incapacitada de una suprema tutela autoculpable». J.G. Hamann: Carta a Christian Jakob Krauss de 18 de diciembre de 1784. En Schriften, ed. crítica de F. Roth. Leipzig, G. Reimer, 1825, vol. VII, p. 193.

${ }_{65}$ Cf. al respecto Canterla, C., Mala noche. El cuerpo, la política y la irracionalidad en el S. XVIII. Madrid, Fundación J. M. Lara, 2009, pp. 221-267.

66 Pöggeler, O., Filosofía y política en Heidegger. Barcelona, Alfa, 1984. Es traducción de la obra original de 1970. 
Heidegger, insatisfecho con el humanismo, planteaba una nueva forma del mismo que se declaraba antihumanista sólo en lo que respecta a situarse en una posición de insatisfacción frente a las viejas formas del mismo, pero que fue visto por muchos como una forma de nihilismo. En sus propias palabras:

«Aquello que es digno de ser cuestionado no es absoluto arrojado a la voracidad de un escepticismo vacío, sino que es confiado al pensar como eso que es propiamente suyo y tiene que pensar ${ }^{67}$.

"Con la ayuda de la tan invocada lógica y ratio consideramos que lo que no es positivo es negativo, que por lo tanto rechaza la razón y en consecuencia merece llevar el sello del desprecio. Estamos tan imbuidos de 'lógica' que todo lo que va en contra de la habitual somnolencia del opinar pasa a ser considerado en el acto como una oposición que debe ser rechazada. Se desecha todo lo que se sale fuera del conocido y querido elemento positivo arrojándolo a la fosa previamente preparada de la mera negación, que lo niega todo, acabando en la nada y consumando de ese modo el nihilismo. Siguiendo esta vía lógica se deja que todo acabe hundiéndose en un nihilismo inventado con ayuda de la lógica.

Pero ¿es verdad que la 'contra' que lleva a cabo un pensar contra las creencias comunes conduce necesariamente a la mera negación y a lo negativo? Eso sólo ocurre - y, eso sí, entonces de modo inevitable y definitivo, es decir, sin permitir una mirada libre sobre otras cosas - cuando se dispone previamente lo que se cree y opina como 'lo positivo' y partiendo de ello se decide de manera absoluta y al mismo tiempo negativa sobre el ámbito de todas las posibles oposiciones. En este modo de proceder se esconde la negativa a exponer a la reflexión eso que se presupone 'positivo', junto con la posición y la oposición, en la que éste se cree a salvo. Con esta permanente invocación a la lógica se despierta la impresión de una total entrega al pensar, cuando precisamente se está abjurando de él.

Que la oposición al 'humanismo' no implica en absoluto la defensa de lo inhumano, sino que abre otras perspectivas, debería resultar un poco más evidente ${ }^{68}$.

Para Heidegger, es humanismo todo pensamiento que medite y cuide «...que el hombre sea humano en lugar de no-humano, "inhumano", esto es, ajeno a su esencia» ${ }^{69}, \mathrm{y}$ por tanto, un humanismo a la altura de la dignidad humana debe reconducirlo a ella, es decir, no sólo debe tener como objetivo definir de modo teórico y abstracto la humanitas, sino combatir la deshumanización de los hombres. Y esta es exactamente - aunque la elaboración sea diferente- la posición de Hamann. Sólo que para éste combatir la deshumanización en los seres humanos equivale a decir — veremos- luchar contra su caída en el terreno de la indignidad, la degradación, la depauperación, es decir, combatir toda filosofía y toda cultura que reduzca a una gran parte de los hombres a mera carnaza sintiente.

El Mago del Norte concibe su nihilismo axiológico como terapéutica cultural y medicina social e individual. La figura del buen filósofo como médico de la cultura aparece en él antes que en Nietzsche, e incluso sus obras completas debían llamarse «Baños terapéuticos» ${ }^{70}$, según él deseaba. La finalidad de la filosofía — recordemos un poema suyo de juventud ${ }^{71}$ es para él hacer frente al dolor existencial, no provocarlo. Por ello, la filosofía abstracta, que

67 Heidegger, M., Op. cit., p. 25.

68 Heidegger, M., Op. cit., pp. 64-66.

69 Heidegger, M., Op. cit., p. 21.

70 El propio apellido Hamann hace referencia - y el filósofo juega con esto— al baño de vapor árabe, Haman o Hamam.

71 «Que la sabiduría nos conceda, amigo, una frente socrática y risueña/Para verter sobre el dolor acerado el bálsamo reparador de la filosofía». Literalmente "...el bálsamo de las cosquilla filosóficas», una alusión, según creo, a la ironía. J.G. Hamann: Freundschftlicher Gesang auf die Heimkunst des Herrn S.G.H. (1751), N II 229 21-22. 
insensibiliza a algunos a los padecimientos, a expensas de exacerbar los de otros, no sólo es, en su opinión, mala filosofía, sino violencia, patología y muerte. Enfermedad de los que la padecen pero también del filósofo que la elabora, incapaz de empatizar con la vida y las desgracias humanas y abocado al sadomasoquismo, la melancolía y la castración.

A Hamann la filosofía consagrada por la Ilustración se le manifiesta como una pantalla que obstaculiza el desarrollo integral y creativo de la vida desde un profundo resentimiento al cuerpo y a la naturaleza, desde una falsa consideración del pensamiento como espacialidad estática de conceptos muertos en vez de como devenir crítico constante y arraigo en la creencia instintiva: la razón abstracta es para él esterilidad e irracionalidad. El nihilismo de Hamann comparte, pues, elementos del posterior nihilismo nietzscheano; pero también del de Heidegger (con quien dialoga Jünger, buen lector de Hamann) en cuanto no permanece, como Nietzsche, aferrado a una filosofía de la subjetividad. Sin embargo, no pretendemos hacer ahora una lectura del mismo reduciendo su filosofía a mero intuitivo anticipo de los grandes. La posición de Hamann es completamente peculiar y hay que analizarla desde sus propias claves internas, mostrándola como lúcida y hábil posición frente a la cuestión del nihilismo que puede tener aún vigencia en nuestros días en algunos aspectos ${ }^{72}$.

Hamann creía en la razón: una razón crítica, pragmática y comunicativa. La filosofía no es para él irracionalismo (aunque frente a cierto tipo de razón lo mejor sea rebelarse), pero tampoco erudición, escolástica o autoritarismo dogmático: es sabiduría basada en la creencia, pragmatismo. Lo que significa en él: instinto, razón biológica, un instrumento de conocimiento vivo basado en el cuerpo, la comunicación y el intercambio - también el sexual- Por ello la filosofía trascendental de Kant, con sus sucesivas purificaciones en el campo del conocimiento - al que separa del lenguaje, del cuerpo situado y de la tradición, consagrando la escisión solipsista entre el yo, la naturaleza y sus semejantes-, su radical demarcación del ámbito del saber del de la creencia moral, y su escisión entre el fenómeno y la cosa en sí reproducida después en las contraposiciones antinómicas dadas como irresolubles, le parecería la peor forma de nihilismo e irracionalismo: la negación de la vida, que era la verdadera, santa y justa razón, sustituida ahora por un nuevo aparataje conceptual.

Pero paradójicamente, fue Hamann el que pasó a la historia de la filosofía como irracionalista. Sin embargo, los abismos a los que llegó la razón en el s. XX ha vuelto los ojos de los intérpretes a sus obras, transformándose su consideración, de forma que en los últimos diez años el interés por su metacrítica de la Ilustración ha ido en aumento. Porque como afirma Heidegger,

«Hace mucho tiempo, demasiado, que el pensar se encuentra en dique seco. Así las cosas, ¿se puede llamar irracionalismo al esfuerzo por reconducir el pensamiento a su elemento ${ }^{73}$

Universidad Pablo de Olavide de Sevilla

ccangon@upo.es

Cinta Canterla

[Artículo aprobado para publicación en diciembre de 2012]

72 Sobre la comparación entre la filosofía de Hamann y la de la postmodernidad, especialmente con Nietzsche, Derrida y Heidegger, cf. la obra ya citada de BETz, J. R., After Einlightenment. The Postsecular Vision of J.G. Hamann, pp. 312-340. También es relevante el reciente libro de SparLing, R. A., Johann Georg Hamann and the Enlightenment Project. Toronto, University of Toronto Press, 2011.

73 Heidegger, M., Op. cit., p. 14. 